[12] DSTU 4536:2006. Oliyi kupazhovani. Tekhnichni umovy (2007). Kyiv, 26.

[13] DSTU ISO 11035:2005. Doslidzhennia sensorne. Identyfikatsiya ta vybyrannia deskryptoriv dlia stvorennia sensornoho spektru za bahatobichnoho pidkhodu (2007). Kyiv, 34.

[14] DSTU 4350:2004. Oliyi. Metodyvyznachennia kyslotnoho chysla (2006). Kyiv, 12.

[15] GOST 26593-85. Masla rastitel'nye. Metod izmereniya perekisnogo chisla (2001). Moscow, 5.

[16] GOST 30418-96. Masla rastitel'nye. Metod opredeleniya zhirno-kislotnogo sostava (1997). Minsk, 7.

\title{
INVESTIGATION OF THE WATER-RETAINING CAPACITY OF THE CARBOHYDRATE COMPLEX OF RYE-WHEAT DOUGH WITH ADDITION OF POLYFUNCTIONAL FOOD SUPPLEMENT "MAGNETOFOOD"
}

\author{
Iryna Tsykhanovska \\ Department of food and chemical technologies \\ Ukrainian Engineering-Pedagogics Academy \\ 16 Universitetska str., Kharkiv, Ukraine, 61003 \\ cikhanovskaja@rambler.ru \\ Victoria Evlash \\ Department of Chemistry, Microbiology and Food Hygiene \\ Kharkiv State University of Nutrition and Trade \\ 333 Klochkivska str., Kharkiv, Ukraine, 61051 \\ evlashvv@gmail.com \\ Alexandr Alexandrov \\ Department of food and chemical technologies \\ Ukrainian Engineering-Pedagogics Academy \\ 16 Universitetska str., Kharkiv, Ukraine, 61003 \\ alexandrov.a.v.a.v@gmail.com

\section{Tetiana Lazareva} \\ Department of food and chemical technologies \\ Ukrainian Engineering-Pedagogics Academy \\ 16 Universitetska str., Kharkiv, Ukraine, 61003 \\ Lazareva_T.A@ukr.net

\section{Tetiana Yevlash} \\ Department of Accounting, Audit and Taxation \\ Kharkiv State University of Nutrition and Trade \\ 333 Klochkivska str., Kharkiv, Ukraine, 61051 \\ tanya@evlash.org.ua
}

\footnotetext{
Abstract

Today in Ukraine the share of low-quality bakery products is near 20-25\%, because they often don't correspond to quality standards and sanitary norms, because of being produced of flour with low bakery properties. That is why new raw material sources, functional ingredients and so on are searched for in bread technologies. For using new raw material and food supplement types, it is necessary to know their functional-technological properties (FTP) that allows to prognosticate the behavior of powder-like raw materials and food supplements in food masses at technological processing and storage of ready products.

The water-retaining capacity (WRC) is one of main functional-technological parameters of carbohydrate-containing raw materials, because it favors the outcome, structural-mechanical properties and quality characteristics of ready products.
} 
The authors introduced "Magnetofood" polyfunctional food supplement for increasing WRC of rye-wheat dough. For grounding the mechanism of forming supramolecular groups in carbohydrate food systems: Magnetofood-polysacharide-water, there was studied the influence of "Magnetofood" food supplement on processes of hydration, swelling and water-retention by rye-wheat starch and rye-wheat flour.

It was established, that introduction of "Magnetofood" food supplement in rye-wheat starch and flour in amounts: 0,10; 0,15; $0,20 \%$ to the mass of starch or flour increases swelling and water-retaining capacity (WRC) of starch and flour: swelling in 1,3-1,5 and 1,5-2,25 times, respectively; WRC in 1,10-1,15 and 1,1-1,3 times, respectively.

The rational dose of "Magnetofood" food supplement $-0,15 \%$ to the mass of dry raw material was experimentally set.

There was studied the influence of "Magnetofood" food supplement on rheological properties of water suspensions of ryewheat starch and flour at different temperatures and different speeds of shift.

It was established, that adding "Magnetofood" in amount $0,15 \%$ favors increasing the effective viscosity of suspensions of experimental samples of starch and flour at temperatures: $(23 \pm 2){ }^{\circ} \mathrm{C}$ and $(40 \pm 2){ }^{\circ} \mathrm{C}$ comparing with control samples in average by $29,0 \%$ - for starch and by $22,0 \%$ - for flour at $23{ }^{\circ} \mathrm{C}$ and by $16,0 \%$ - for starch and by $10,0 \%$ - for flour at $40^{\circ} \mathrm{C}$.

There was studied the dynamics of changing viscosity of colloid solutions of starch and flour, enriched with "Magnetofood" in amount $0,15 \%$ to the mass of dry raw material in the keeping process at different temperatures and shift speed $9 \mathrm{~s}-1$.

There was established the increase of viscosity of suspensions of rye-wheat starch and flour in the process of infusion (especially at adding "Magnetofood") that is connected with continuing hydration and swelling process.

It was demonstrated, that the temperature increase of the colloid system from $(23 \pm 20){ }^{\circ} \mathrm{C}$ to $(40 \pm 2){ }^{\circ} \mathrm{C}$ favors the increase of its viscosity - both at the initial moment and in infusion process during $30 \mathrm{~min}$ in average by $20,0-25,0 \%$ at the expanse of the aforesaid processes. Moreover, adding "Magnetofood" accelerates and intensifies the processes of swelling and hydration of experimental samples of rye-wheat starch and flour comparing with control ones.

The received experimental data may be used at elaborating the technology of rye-wheat bread, enriched with "Magnetofood" food supplement; and also at elaborating innovative technologies of carbohydrate food systems.

The results of this study may be used at elaborating recipes and technologies of carbohydrate-containing food products for increasing their viscosity, water-retaining and stabilizing capacities.

Keywords: "Magnetofood" food supplement, rye-wheat starch and flour, swelling capacity, water-retaining capacity, effective viscosity.

\section{Introduction}

Today in Ukraine the share of low-quality bakery products is near $20-25 \%$, because they often don't correspond to quality standards and sanitary norms, because of being produced of flour with low bakery properties $[1,2]$. As a result, bakery enterprises must use improvers for increasing the quality of flour and correcting its shortcomings.

At modern food enterprises there are used diverse food and bio-supplements, improving the quality of raw materials and ready products, especially water-absorbing capacity (WAC) and water-retaining one (WRC). The increase of WAC and WRC favors the improvement of the quality and output of ready products; decrease of their prime cost [3].

For increasing WAC of flour and WRC of dough semi-products, bakery industry uses mineral compounds (ammonium salts of orthophosphate acid, sodium, potassium orthophosphates) [4].

Diverse biologically active substances of vegetable, fruit and herbal supplements [5, 6] and also bio-compounds of different chemical compositions: soya, chick-pea [7, 8]; enzymes, micro-water plants and so on [9-11] are widely used in bakery technologies for increasing WRC of dough semi-products.

The analysis of information sources [1-11] demonstrates the absence of polyfunctional food supplements of complex action, especially nanopowder ones that increase hydration and water-retaining capacity of both raw materials and semi-products and also ready products of them.

The revealed properties of "Magnetofood" food supplement allow to recommend it for introduction in food systems, especially in rye-wheat dough semi-products [12-17]. The aim of introducing "Magnetofood" is to increase WRC of rye-wheat dough. It allows to improve the output, 
organoleptic, physical-chemical and structural-mechanical characteristics of dough systems and bakery products of them.

\section{Materials and Methods}

\section{1. Studied materials and equipment, used in the experiment}

The study of the influence of "Magnetofood" polyfunctional food supplement for water-absorbing (WAC) and water-retaining capacity (WRC) and also viscosity of rye-wheat starch and flour was realized on the model systems:

- sample 1 control - dry rye-wheat starch that is the mixture of rye starch of the first grade [TC 10.62.11-668-37676459-2017. Packed starch. Scentific-production center "Agrofoodind"] and wheat starch of the higher grade [FS USSR 1490-90 Wheat starch. Technical conditions]. The ratio between rye starch and wheat one is 60:40;

- sample 2 - dry rye-wheat starch with "Magnetofood" polyfunctional food supplement in amount $0,10 \%$ to the starch mass as powder;

- sample 3 dry rye-wheat starch with "Magnetofood" polyfunctional food supplement [TC U 10.8-202.3017824-001:2018 - Food supplement based on iron acids "Magnetofood"] in amount $0,15 \%$ to the starch mass as powder;

- sample 4 - dry rye-wheat starch with "Magnetofood" polyfunctional food supplement in amount $0,20 \%$ to the starch mass as powder;

- sample 5 control - rye-wheat flour according to SSU-F 4583:2006. The ratio between peeled rye and wheat flour of the first grade is 60:40 according to the basic recipe of rye-wheat bread "Darnitsky" [18];

- sample 6 - rye-wheat flour with "Magnetofood" polyfunctional food supplement in amount $0,10 \%$ to the flour mass as powder [14];

- sample 7 - rye-wheat flour with "Magnetofood" polyfunctional food supplement in amount $0,15 \%$ to the flour mass as power [14];

- sample 8 - rye-wheat flour with "Magnetofood" polyfunctional food supplement in amount $0,20 \%$ to the flour mass as powder [14].

Fig. 1 presents the experimental samples of rye-wheat starch, the Fig. 2 - experimental samples of rye-wheat flour.

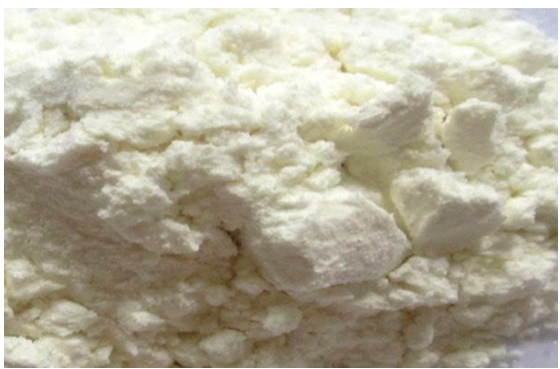

$a$

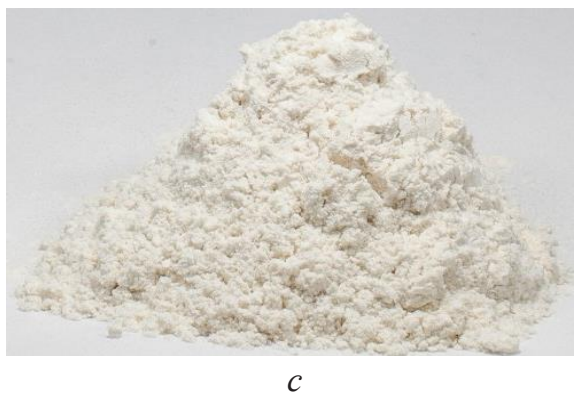

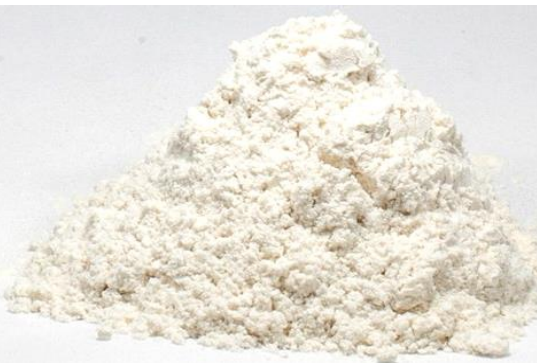

$b$

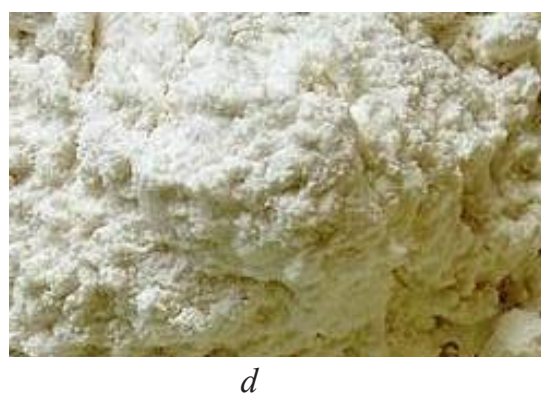

Fig. 1. Experimental samples of rye-wheat starch: $a$-sample $1 ; b$-sample $2 ; c$-sample $3 ; d$-sample 4 


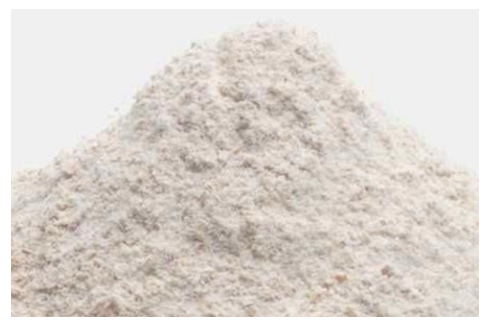

$a$

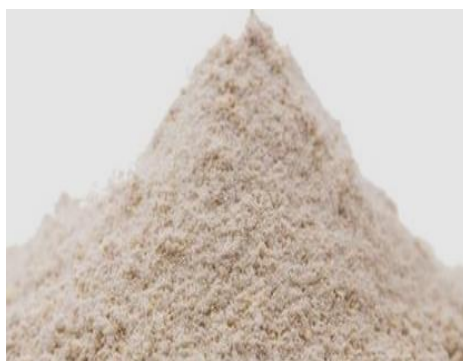

$c$

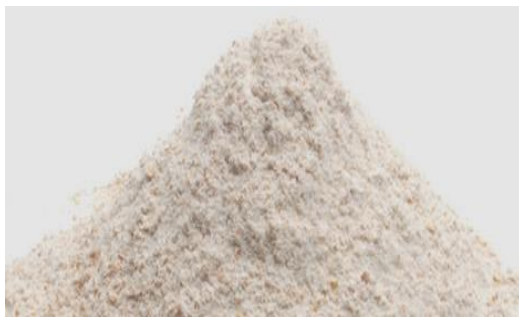

$b$

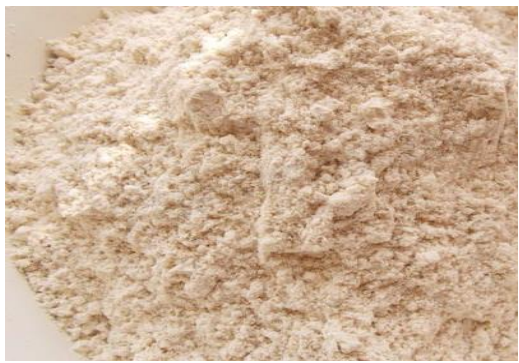

$d$

Fig. 2. Experimental samples of rye-wheat flour: $a$-sample $5 ; b$-sample $6 ; c$-sample $7 ; d$-sample 8

The mass of starch and flour was calculated by the electric analytic scales of ANG series (Ukraine), swelling and water-retaining capacities (WRC) - by the mixer of PE-8100 model (made by Ekros, group of companies) and centrifuge CM-6M with rotor 6M (made by «ELMI» Latvia). Viscosity was calculated on the rotary viscosimeter "Reotest $-2 »$ : working body - system of cylinders S-S1 (Russia).

Fig. 3 presents the devices, used for studying physical-chemical and rheological properties of rye-wheat starch and rye-wheat flour.

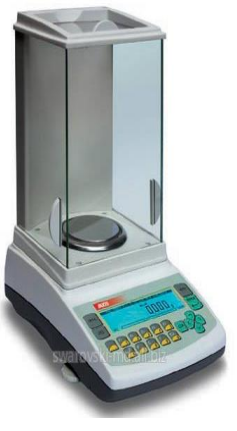

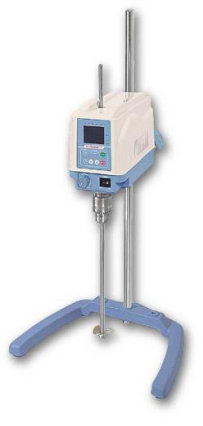

$b$

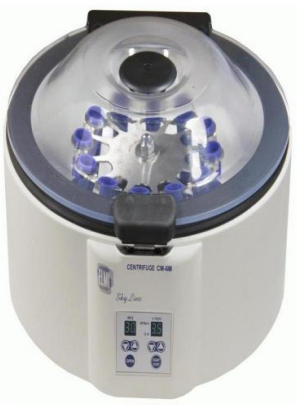

C

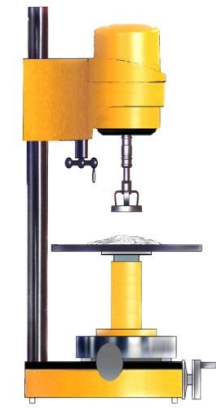

$d$

Fig. 3. Devices, used for studying parameters of dough and bread: $a$ - electronic analytic scales ANG; $b$ - laboratory mixer PE-8100; $c$ - centrifuge CM-6M with rotor $6 \mathrm{M} ; d$ - rotary viscosimeter "Reotest-2»

\section{2. Methods of determining physical-chemical and rheological parameters}

The work studied the following functional-technological properties: water-retaining capacity (WRC), swelling capacity, viscosity of suspensions with water. The standard research methods, considered below [19-22] and SSU-F 4583:2006 were used at the experiment.

Swelling capacity (in $\mathrm{cm}^{3} / \mathrm{g}$ ) was calculated by infusing $1 \%$ water suspension during a day. The swelling capacity was assessed as the maximal amount of water that an object can absorb and retain before reaching the dynamic balance, related to the batch mass [19, 20]. 
Course of analysis: The batch of a product with mass $1 \mathrm{~g}$ was transferred in a glass with capacity $100 \mathrm{~cm}^{3}$ that was preliminarily filled with $80 \mathrm{~cm}^{3}$ of distilled water. After accurate mixing, suspension was transferred in a measuring cylinder. Its content was added with distillate up to $100 \mathrm{~cm}^{3}$. Suspension was accurately mixed one more time and left at $20-23^{\circ} \mathrm{C}$ for 24 hours, then the boundary of separation of two phases was set. At certain swelling there is observed the even distribution of a product along the whole volume. At incomplete swelling two phases are created in the cylinder: upper liquid, transparent, almost doesn't contain a product, and the low one, opaque, with a swelled product. Two parallel calculations were realized. At incomplete swelling, the swelling capacity of a product in $\mathrm{cm}^{3} / \mathrm{g}$ was calculated by the ratio between the product volume after infusing to the batch mass. The final result of the analysis was considered as the mean arithmetical value of the results of two previous calculations.

Water-retaining capacity - WRC (in \%) was calculated by Shoh method as an amount of water, absorbed and retained by the raw material component at infusing and centrifuging of water suspension [21-22].

Course of analysis: the product batch of $0,8 \mathrm{~g}$ was added with $40 \mathrm{ml}$ of distilled water, kept in the water exceed at permanent mixing during $30 \mathrm{~min}$ at temperatures $(23 \pm 2)$ and $(40 \pm 2)^{\circ} \mathrm{C}$ then transferred in a centrifuge test-tube and centrifuged during $5 \mathrm{~min}$ at $4500 \mathrm{turns} / \mathrm{min}$. The liquid phase was poured in a measuring test-tube. The amount of bound water - W (in g) was calculated by weighing the test-tube together with residue by subtraction of the empty test-tube mass and sample batch mass. WRC (in \%) was calculated by the ratio of bound water $\mathrm{W}$ to the starch mass.

Viscosity (in Pa-s) is calculated on the rotary viscosimeter "Reotest-2". For that, there were prepared $13 \%$ water suspensions of rye-wheat starch and flour. The choice of concentration was conditioned by getting solutions with viscosity, optimal for studying on this device. Samples' viscosity was measured during $30 \mathrm{~min}$ after each $10 \mathrm{~min}$ at temperatures $(23 \pm 2){ }^{\circ} \mathrm{C}$ and $(40 \pm 2){ }^{\circ} \mathrm{C}$. Keeping samples of colloid solutions and water suspensions in time to the moment of measuring viscosity is farther denoted as infusion $[19,20]$.

\section{Results}

Fig. 4, 5 present the influence of "Magnetofood" food supplement on the swelling capacity and water-retaining capacity (WRC) of rye-wheat starch and rye-wheat flour in experimental samples respectively.

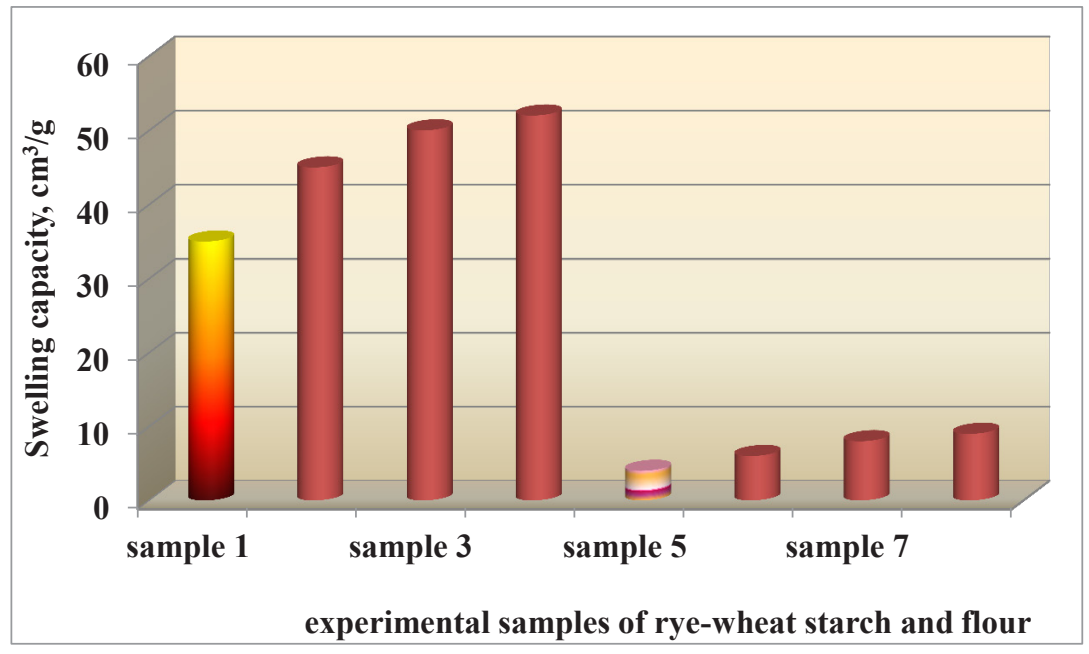

Fig. 4. Influence of "Magnetofood" food supplement on the swelling capacity of experimental samples of rye-wheat starch and flour

The analysis of the experimental data (Fig. 4, 5) demonstrates that introduction of "Magnetofood" polyfunctional food supplement in rye-wheat starch and flour favors the increase of the swelling capacity and WRC of starch and flour. Comparing with the control samples (without 
"Magnetofood"), the swelling capacity of the experimental samples with "Magetofood" increases: in 1,3-1,5 times and 1,5-2,25 times for model systems, based on starch and flour respectively. Comparing with the control samples (without "Magnetofood"), WRC of the experimental samples with "Magnetofood" increases: in 1,10-1,15 times and 1,1-1,3 times for model systems, based on starch and flour respectively. It is connected with the fact that polarized nanoparticles (NP) of "Magnetofood" food supplement modify macromolecules of polysaccharides, change and stabilize their construction, favoring intensification of solubility and swelling, even in cold water. "Magnetofood" food supplement is able to create hydrophilic solvate associates with carbohydrate complexes of starch and flour that favors increasing of the swelling capacity and WRC of starch and flour.

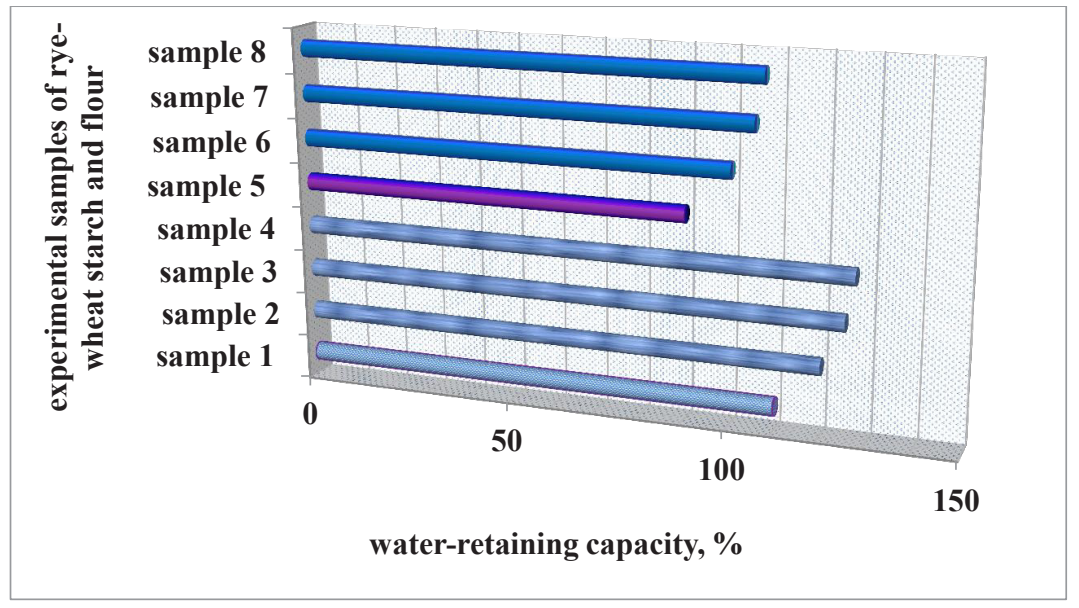

Fig. 5. Influence of "Magnetofood" food supplement on the water-retaining capacity of experimental samples of rye-wheat starch and flour

Fig. 6, 7 present the results of studying the influence of "Magnetofood" food supplement in the optimal amount $(0,15 \%$ to the starch or flour mass) on the viscosity of water suspensions of the experimental samples of rye-wheat starch and rye-wheat flour at temperatures $(23 \pm 2)$ and $(40 \pm 2){ }^{\circ} \mathrm{C}$ respectively.

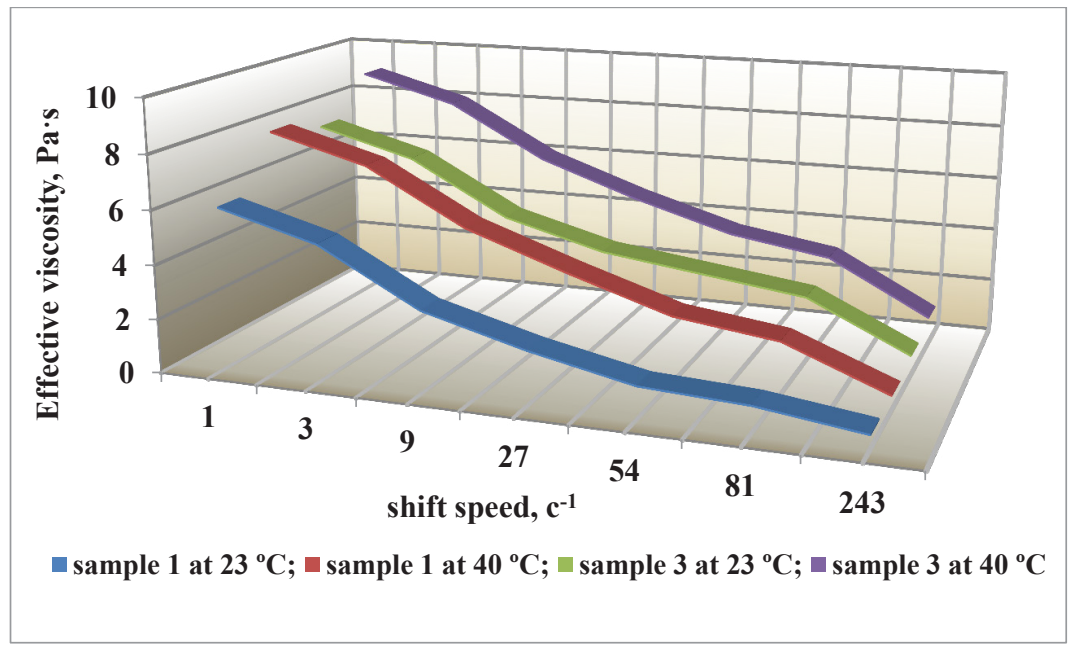

Fig. 6. Influence of "Magnetofood" food supplement on the effective viscosity of $13 \%$ water suspensions of the experimental samples of rye-wheat starch at different shift speeds and temperatures $(23 \pm 2){ }^{\circ} \mathrm{C}$ and $(40 \pm 2){ }^{\circ} \mathrm{C}$

The data of fig. 6 and 7 testify that the adding "Magnetofood" food supplement favors the increase of viscosity of suspensions of rye-wheat starch and flour at both temperatures comparing 
with the control samples in average by $29,0 \%$ - for starch and by $22,0 \%$ - for flour at $23{ }^{\circ} \mathrm{C}$ and by $16,0 \%$ - for starch and by $10,0 \%$ - for flour at $40{ }^{\circ} \mathrm{C}$. It is conditioned by ramification of polymer links, appearance of cavitates, clathrates and lateral links that move main links of biopolymers apart. As a result, hydration, swelling and WRC increase (Fig. 4, 5). Under the influence of the applied shift tension these aggregates gradually collapse, at that in samples with "Magnetofood" slower. It explains the high pseudoplasticity of water suspensions of the experimental samples of starch and flour. As a result, their viscosity decreases (Fig. 6, 7).

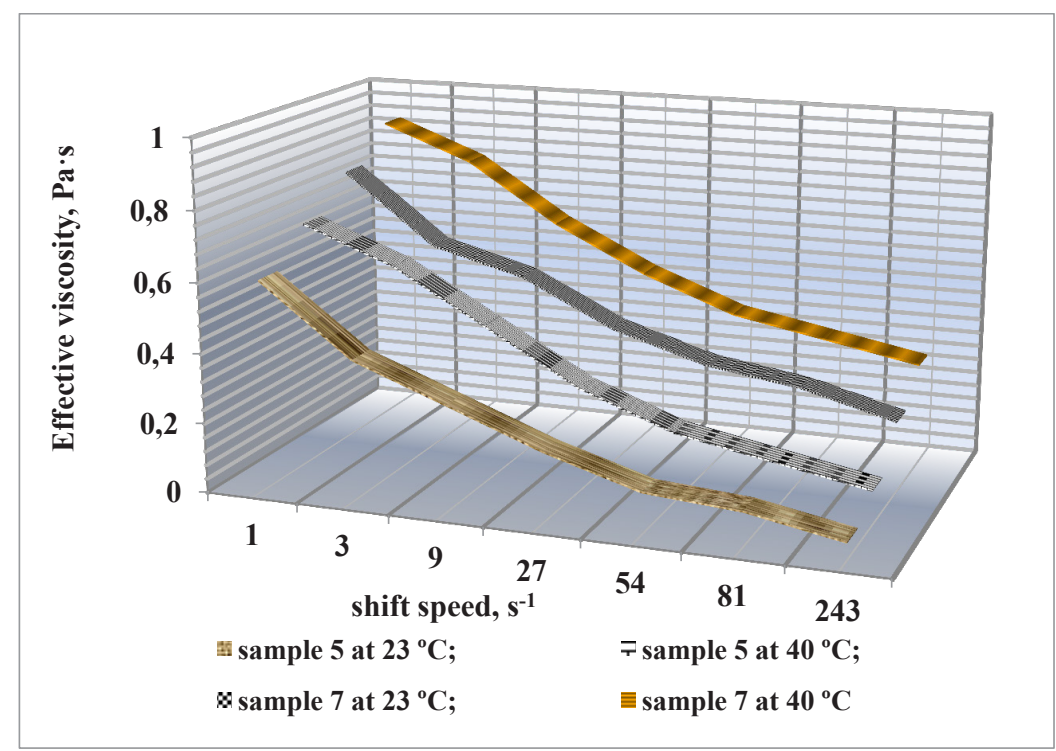

Fig. 7. Influence of "Magnetofood" food supplement on the effective viscosity of $13 \%$ water suspensions of the experimental samples of rye-wheat flour at different shift speeds and temperatures $(23 \pm 2){ }^{\circ} \mathrm{C}$ and $(40 \pm 2){ }^{\circ} \mathrm{C}$

The dynamics of changing viscosity of colloid solutions of starch and flour in the infusion process at different temperatures and shift speed $9 \mathrm{~s}^{-1}$ is presented on Fig. 8,9 respectively.

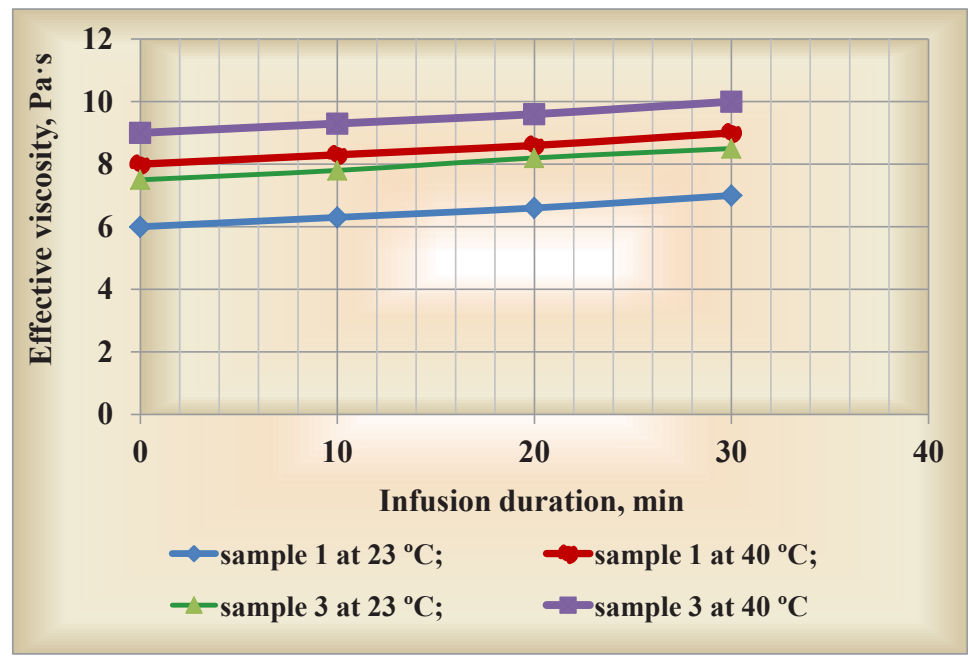

Fig. 8. Influence of "Magnetofood" food supplement on the effective viscosity of $13 \%$ water suspensions of the experimental samples of rye-wheat starch at shift speed $9 \mathrm{~s}^{-1}$ and temperatures $(23 \pm 2)^{\circ} \mathrm{C}$ and $(40 \pm 2){ }^{\circ} \mathrm{C}$ and 30 min of infusion

The increase of viscosity of starch and flour solutions in the process of infusion is connected with continuing the processes of swelling and hydration. The increase of the temperature in the system from 
$(23 \pm 20)^{\circ} \mathrm{C}$ to $(40 \pm 2)^{\circ} \mathrm{C}$ favors the increase of viscosity of these solutions both in the initial moment of time and at infusion during $30 \mathrm{~min}$ at the expanse of acceleration of the aforesaid processes.

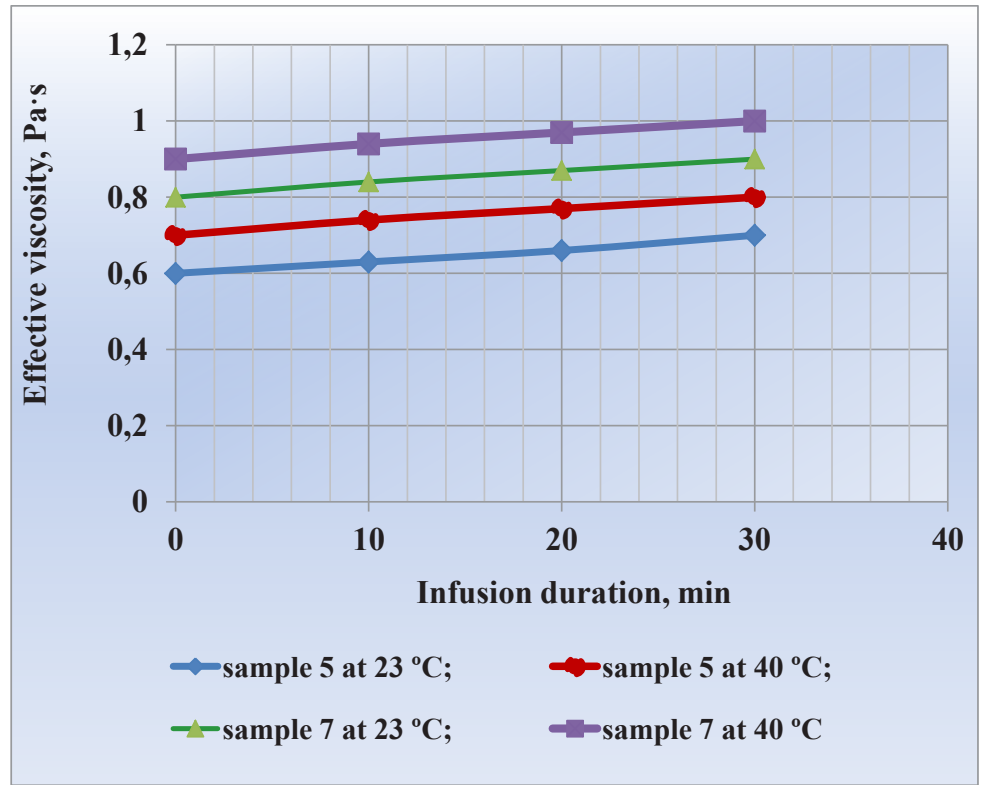

Fig. 9. Influence of "Magnetofood" food supplement on the effective viscosity of $13 \%$ water suspensions of the experimental samples of rye-wheat flour at shift speed $9 \mathrm{~s}^{-1}$ and temperatures

$(23 \pm 2){ }^{\circ} \mathrm{C}$ and $(40 \pm 2){ }^{\circ} \mathrm{C}$ and 30 min of infusion

Moreover adding "Magetofood" accelerates and intensifies the processes of hydration and swelling of the experimental samples of rye-wheat starch and flour comparing with the control samples.

The results of the studies prove the important functional-technological property of "Magnetofood" food supplement - water-retaining capacity. The received experimental data may be used in the technology of rye-wheat bread, enriched with "Magnetofood" food supplement for stabilizing properties of semi- and ready products at production and storage, for getting products with high consumption characteristics.

\section{Conclusions}

The methods of studying starch, flour and models systems, based on them, presented in this work, may be used at studying the influence of different supplements-improvers on functional-technological characteristics, especially water-retaining capacity, of carbohydrate-containing food systems (for example, dough ones).

Using the considered methods in future, scientists can study the influence of different food ingredients on swelling, water-retaining capacities of food systems, based on starch and flour and also ready products more detail; to study rheological properties, processes of dissolution, swelling, stabilization of the structure more detail.

The shortcoming of this work is the fact that the effect of the offered methods is considered only on one type of model systems - rye-wheat, and the influence of only one food supplement on this model system was analyzed - "Magnetofood" polyfunctional food supplement. It is also unknown, how this supplement influences technological parameters of dough of another recipe composition (of other flour sorts).

The positive side is that the research methods, presented in this work, may be used at studying functional-technological characteristics, especially swelling, viscosity, water-retaining capacity, of not only rye-wheat dough masses and ready products, but also rye, wheat and so on. Moreover, the research results may be used in the technology of rye-wheat bread with adding "Magnetofood" food supplement. 


\section{References}

[1] Obzor rynka hlebobulochnyh i konditerskih izdeliy Ukrainy (2012). Hlebopekarskoe i konditerskoe Delo, 3, 6 .

[2] Volkova, S. F., Zolotuhina, A. O. (2012). Sostoyanie i perspektivy razvitiya hlebopekarnoy promyshlennosti Ukrainy. Ekonomika kharchovoi promyslovosti, 3 (15), 51-55.

[3] Buldakov, A. (2008). Pishchevye dobavki. Moscow: SPb, 280.

[4] Matveeva, I. V., Velickaya, I. G. (1998). Pishchevye dobavki i hlebopekarnye uluchshiteli v proizvodstve hleba. Novosebirsk: Sib. univ. izd-vo, 328.

[5] Chugunova, O. V., Pastushkova, E. V. (2015). Modelirovanie organolepticheskih pokazateley hleba s rastitel'nymi dobavkami. Vestnik YuUrGU. Seriya «Pishchevye i biotekhnologii», 3 (4), 80-87.

[6] Tamazova, S. YU., Lisovoy, V. V., Pershakova, T. V., Kazimirova, M. A. (2016). Pishchevye dobavki na osnove rastitel'nogo syr'ya, primenyaemye v proizvodstve hlebobulochnyh i muchnih konditers'kih izdeliy. Politematicheskiy setevoy elektronnyy nauchnyy zhurnal KubGAU, 122 (08), 1-8.

[7] Citrusovye volokna Herbacel AQ Plus - tip N. Specifikacii dlya pishchevyh dobavok i receptury. Available at: http://specin.ru/kletchatka/109.htm

[8] Ngemakwe, P. N., Le Roes-Hill, M., Jideani, V. (2014). Advances in gluten-free bread technology. Food Science and Technology International, 21 (4), 256-276. doi: 10.1177/1082013214531425

[9] Bird, L. G., Pilkington, C. L., Saputra, A., Serventi, L. (2017). Products of chickpea processing as texture improvers in gluten-free bread. Food Science and Technology International, 23 (8), 690-698. doi: $10.1177 / 1082013217717802$

[10] García-Segovia, P., Pagán-Moreno, M. J., Lara, I. F., Martínez-Monzó, J. (2017). Effect of microalgae incorporation on physicochemical and textural properties in wheat bread formulation. Food Science and Technology International, 23 (5), 437-447. doi: 10.1177/1082013217700259

[11] Boubaker, M., Omri, A. E., Blecker, C., Bouzouita, N. (2016). Fibre concentrate from artichoke (Cynara scolymus L.) stem by-products: Characterization and application as a bakery product ingredient. Food Science and Technology International, 22 (8), 759-768. doi:10.1177/1082013216654598

[12] Tsykhanovska, I., Evlash, V., Alexandrov, A., Svidlo, K., Gontar, T. (2017). Influence of the polyfunctional food supplement "Magnetofood" on the quality of the wheat-rye bread "Kharkiv Rodnichok" in the storage process. Eastern-European Journal of Enterprise Technologies, 5 (11 (89)), 61-70. doi: 10.15587/1729-4061.2017.111522

[13] Tsykhanovska, I., Evlash, V., Alexandrov, A., Svidlo, K., Gontar, T. (2017). Research quality of the wheat-rye bread with addition of the polyfunctional food supplement «Magnetofood». EUREKA: Life Sciences, 5, 45-52. doi: 10.21303/2504-5695.2017.00431

[14] Tsykhanovska, I., Evlash, V., Alexandrov, A., Lazarieva, T., Svidlo, K., Gontar, T. (2017). Design of technology for the rye-wheat bread "Kharkivski rodnichok" with the addition of polyfunctional food additive "Magnetofood." Eastern-European Journal of Enterprise Technologies, 6 (11 (90)), 48-58. doi: $10.15587 / 1729-4061.2017 .117279$

[15] Tsykhanovska, I., Evlash, V., Alexandrov, A., Lazareva, T., Svidlo, K., Gontar, T. (2017). Research into technological indicators of a rye-wheat dough semi-finished product with the addition of the polyfunctional food supplement "Magnetofood." EUREKA: Life Sciences, 6, 43-50. doi: 10.21303/25045695.2017 .00511

[16] Tsykhanovska, I., Evlash, V., Alexandrov, A., Lazarieva, T., Svidlo, K., Gontar, T. et. al. (2018). Substantiation of the mechanism of interaction between biopolymers of ryeandwheat flour and the nanoparticles of the magnetofood food additive in order to improve moistureretaining capacity of dough. Eastern-European Journal of Enterprise Technologies, 2 (11 (92)), 70-80. doi: 10.15587/1729-4061.2018.126358

[17] Tsykhanovska, I., Evlash, V., Alexandrov, A., Lazareva, T., Svidlo, K., Gontar, T. et. al. (2018). Investigation of the moisture-retaining power of rye-wheat gluten and flour with polyfunctional food supplement “Magnetofood." EUREKA: Life Sciences, 2, 67-76. doi: 10.21303/2504-5695.2018.00611

[18] Ershov, P. S. (2004). Sbornik receptur na hleb i hlebobulochnye izdeliya. Sankt-Peterburg: Profi-inform, 190.

[19] Koryachkina, S. Ya., Berezina, N. A., Hmeleva, E. V. (2011). Metody issledovaniya svoystv syr'ya, polufabrikatov i gotovoy produkcii. Metody issledovaniya svoystv rastitel'nogo syr'ya. FGOU VPO «Gosuniversitet-UNPK», 297.

[20] Kabachnyi, V. I., Hrytsan, L. D., Tomarovska, T. O. et. al.; Kabachnyi, V. I. (Ed.) (2015). Fizychna ta koloidna khimiya: bazovyi pidruch. dlia stud. vyshch. farmats. navch. zakl. (farmats. f-tiv) IV rivnia akredytatsiyi. Kharkiv: NFaU: Zoloti storinky, 432.

[21] Rihter, M., Augustat, Z., SHirbaum, F. (1975). Izbrannye metody issledovaniya krahmala. Moscow: Pishchevaya promyshlennost', 183.

[22] Renzyaeva, T. V., Poznyakovskiy, V. M. (2009). Vodouderzhivayushchaya sposobnost' syr'ya i pishchevyh dobavok v proizvodstve muchnyh konditerskih izdeliy. Hranenie i pererabotka sel'hozsyr'ya, 8, 35-38. 